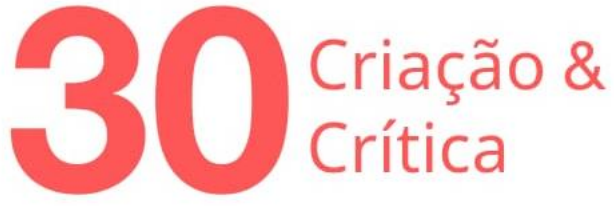

\section{UM PÁSSARO DE CANTO PARTICULAR, LITERÁRIO: A PAISAGEM ESCRITURAL BARTHESIANA E A INSCRIÇÃO DA MORTE NA VIDA}

\author{
Kaio Fidelis ${ }^{1}$ \\ Guilherme Massara Rocha ${ }^{2}$
}

\begin{abstract}
Resumo: Percorrendo o Diário de luto de Roland Barthes, este artigo propõe uma reflexão sobre o ponto de virada na escrita barthesiana nomeado por ele de Vita Nova. Acompanhamos esse movimento a partir de três inscrição recolhidas de seu diário: seu processo de escrita, sua narrativa onírica e seu investimento libidinal. Atravessado e profundamente marcado pelo luto de sua mãe, Barthes inscreve um projeto de romper com sua lógica de escrita anterior, acrescentando um desejo por uma nova forma de escrita. Todavia, extraímos a partir desse percurso no diário um intervalo escrito entre a continuidade mortífera e a particularidade entoada pela literatura.
\end{abstract}

PALAVRAS-CHAVE: Barthes, luto, escrita, sonho, literatura, psicanálise.

\section{A BIRD WITH A SPECIAL, RATHER LITERARY SONG: \\ THE BARTHESIAN SCRIPTURAL LANDSCAPE AND THE INSCRIPTION OF DEATH IN LIFE}

ABSTRACT: From Roland Barthes' Diary of Mourning, the article poses a consideration on the turning point in the Barthesian writing he named Vita Nova, following this movement in three inscriptions collected from his diary: his writing process, dream narratives and libidinal investment. Subsequent to his mother's death, Barthes inscribes a fracture within his writing logic, adding a desire for literature and for a new form of scriptural landscape. We then extracted from this journey in the diary a written interval between a deadly continuity and the singularity sung by literature.

KEYWORDS: Barthes, mourning, writing, dream, literature, psychoanalysis.

Roland Barthes, de quem os primeiros livros publicados datam da década de 50, escreve ao final da década de 70 o Diário de Luto. A morte de sua mãe Henriette Binger, no dia 25 de outubro de 1977, leva a essa escrita. A primeira entrada desse diário data de 26 de outubro, um dia depois; a última, 21 de junho de 1978; algumas outras notas se seguem, sob outros títulos, ainda que reunidos no mesmo volume.

No contexto de sua publicação em 2009, François Wahl, editor de Barthes em vida, se colocou publicamente contrário à publicação, fazendo menção ao

\footnotetext{
${ }^{1}$ Psicanalista. Doutorando (Bolsista CAPES) e Mestre em Psicologia (Estudos Psicanalíticos) pela UFMG. Membro do Centro de Pesquisas "Outrarte: psicanálise entre ciência e arte" da UNICAMP. Graduado em Psicologia pela UFMG. E-mail: kaiobfidelis@gmail.com

2 Psicanalista. Professor Adjunto do Departamento de Psicologia da UFMG. Membro da International Society of Philosophy and Psychoanalysis e da Fédération Européenne de Psychanalyse (FEDEPSY). E-mail: massaragr@gmail.com
} 


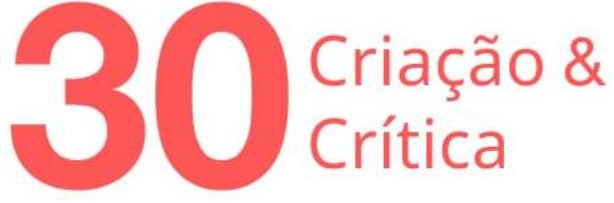

caráter pessoal das notas que compõem isso que se dá a ver ao público (AESCHIMAN, 2009). Éric Marty, editor das obras completas de Barthes, além de aludir ao título dado por Barthes onde ele lê um ato de nomeação, ecoa também as palavras do irmão de Roland, Michel Salzedo: "trinta anos após a morte de um escritor, ninguém é dono de sua obra" (AESCHIMAN, 2009, s. p.). Mais do que reconhecer a propriedade ou a posse disso que vem a público, cabe tentar recolher aqui quais as possibilidades de efeitos sob os leitores desses escritos íntimos.

Como passar da experiência singular para a transmissão? Como fazer passar? Como deixar passar? O que interessa de uma experiência singular para o leitor? Quais modos para fazer passar? Quais formas para deixar passar? Essas perguntas sobre a transmissão são perguntas desde sempre da psicanálise, da literatura, da filosofia, ou pelo menos de alguma psicanálise, alguma literatura, alguma filosofia. A forma interessa tanto quanto o conteúdo do que passa. O Diário de Luto de Barthes apresenta aqui formas possíveis para a transmissão da experiência singular de luto ou de sua inscrição a partir da escrita.

Colocar algo de si: essa era a advertência e, nos parece, também a tarefa dada por Lacan (1998), herdada dele, um pouco como sua afirmação sobre a transmissão da psicanálise: "Tal como agora chego a pensar, a psicanálise é intransmissível. É bem chato. É bem chato que cada psicanalista seja forçado - pois é preciso que ele seja forçado - a reinventar a psicanálise" (LACAN, 2015, s. p.). Mas, dada a tarefa, surge também o assombro: quanto de si cabe em um texto? Qual a medida, mesmo que ela não exista? Tomando os modos de viver fazendo com a morte aqui inscritos, quanto de morte é suportável em uma vida? Outro semmedida. Outra tarefa de invenção.

Em nossa leitura desse texto, afetada por lutos íntimos e também pelo luto público dos mais de quinhentos mil nomes, vidas e histórias perdidas (até então) na pandemia atravessada pela escrita deste texto, recortamos três incidentes ou talvez três nomes pelos quais os caminhos do luto de Barthes podem ser sondados: a escrita, o sonho e o investimento libidinal.

\section{A escrita do luto}

O principal movimento que gostaríamos de desenvolver nesse tópico é já bastante conhecida do público leitor de Barthes: que a morte de sua mãe se relaciona com o que ele chama de o meio da vida desencadeando no projeto de escrita nomeado Vita Nova. O que nos interessa aqui é observar na escrita do luto de Barthes, não a origem, mas alguma inscrição dessa outra vida, nova.

A ideia de vita nova aparece desde Dante, passando por Jacques Roubaud, mas encontra em Barthes uma renovação. Essa noção aponta para uma ruptura, mas, como descreve Eduardo Sterzi, em Barthes essa ruptura está circunscrita na 


\section{Criação \&}

escrita: "uma ruptura, uma interrupção, pela qual se instaura «uma nova prática de escrita» (ou de "escritura»), antes que qualquer mudança «de ideias» («de conteúdo, de doutrina, de teoria, de filosofia, de método, de crença»)" (STERZI, 2006, p. 59). Como afirma o próprio Barthes: "para quem escreve, para quem escolhe escrever, não pode haver 'vida nova', parece-me, que não seja a descoberta de uma nova prática de escrita" (BARTHES, 1988, p. 291).

Flavia Trocoli (2017) aponta que, lendo Proust, Barthes tenta desarticular a associação imediata da morte da mãe e o início da escrita, reconhecendo no autor de Em busca do tempo perdido o nascimento de um outro modo de dizer eu, uma outra enunciação. Valendo-nos desse gesto de leitura feito por Barthes, nos interessamos aqui não por essa relação colada entre a morte da mãe e uma outra escrita, mas pelo que, a partir de algum intervalo (escrito), vai dando lugar a um novo.

Entre a morte de Henriette Barthes (25 de outubro de 1977) e o primeiro manuscrito do projeto de escrita Vita Nova (Longtemps, je me suis coche de bonné heure, conferência proferida em 19 de outubro de 1978) há um intervalo: esse intervalo é escrito. Nesse intervalo há, como Barthes reconhece em Proust, hesitação e afirmação. E acrescentamos: investimento e desinvestimento, trabalho - sobretudo, trabalho de luto. Nas palavras de Barthes:

Não acredito numa determinação proveniente da biografia; claro que os acontecimentos pessoais podem ter influência decisiva sobre uma obra; mas essa influência é complexa, tem efeito retardado: ninguém duvida de que a morte da Mãe tenha de algum modo 'fundado' a Busca; mas a Busca só foi lançada quatro anos depois dessa morte. Acredito mais numa descoberta de ordem criativa: Proust encontrou um meio, talvez meramente técnico, de fazer a obra "resistir", de "facilitar" sua escrita (no sentido operacional em que fala de "facilitadores"). (BARTHES, 2004, p. 228)

Reconhecendo as influências dos acontecimentos, mais do que uma determinação biográfica, Barthes aposta nesse efeito retardado, de onde advém uma nova forma, uma nova enunciação em Proust. Esse efeito retardado é próprio da temporalidade do luto, alongada, demorada. Entre a hesitação em viver sua vida após a perda de sua mãe e a afirmação de algo novo que vai surgindo de modo retardado, Barthes reconhece o rompimento com um tempo passado, inclusive com um tempo de escrita passado.

Em entrada do diário do dia 25 de maio de 1978, ele escreve: "Quando mam. estava viva (isto é, toda minha passada), eu estava na neurose por medo de perdê-la" (BARTHES, 2011, p. 126). Toda a minha vida passada: a morte da mãe impõe uma vida nova, na qual Barthes crê inclusive que o medo da perda é rompido. Isso tem lugar sobretudo na escrita: 


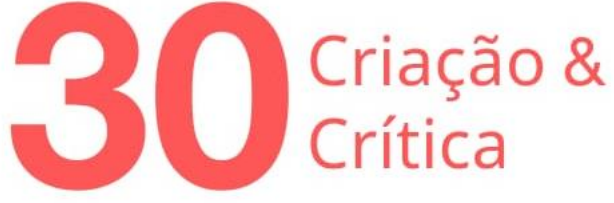

Quanto a mim, neste ponto de minha vida (em que mam. está morta), eu era reconhecido (pelos livros). Mas, coisa estranha - talvez falsa? -, tenho o sentimento de que, ela não estando mais aqui, preciso tornar-me reconhecido novamente. Não fazendo mais um livro qualquer: a ideia de continuar como no passado, indo de livro a livro, de curso a curso, tornou-se imediatamente mortífera (eu via isso até minha morte). (BARTHES, 2011, p. 130)

Um sentimento surge, uma necessidade de reconhecimento, não do mesmo lugar. É preciso continuar, mas continuar de outro modo. Continuar no mesmo fluxo, passando de livro a livro, de curso a curso seria ignorar o acontecimento da morte e, mais do que isso, redobrá-la, já que, além da morte da mãe que impõe o luto, essa continuidade se tornaria mortífera para Barthes. No trecho acima, Barthes prefere sacrificar uma escrita anterior que acontecia nesse fluxo ininterrompível do que sacrificar sua própria vida, já que esse ritmo se coloca ou é sentido como insuportável.

A sensação de ruptura do fluxo (livro a livro, curso a curso) sugere a incidência do trauma sobre a cadeia significante. Não 'continuar' talvez diga da presença real da morte, que desestabiliza a relação desse sujeito com a ordem simbólica e inaugura outra coisa. Talvez, nesse contexto, ser reconhecido signifique também ser re-lido.

Nesse intervalo onde uma nova escrita e uma nova vida vão se delineando, Barthes escreve também um livro sobre a fotografia, A câmara clara. Ali, Barthes localiza um par que o permite pensar as fotografias, entre elas uma fotografia de sua mãe. De um lado, tem-se o studium "uma espécie de investimento geral, ardoroso, é verdade, mas sem acuidade particular" (BARTHES, 1984, p. 45); de outro, como uma flecha ou uma mancha que desconjunta tem-se "esse acaso que nela [a foto] me punge" (BARTHES, 1984, p. 46), o punctum. Talvez pudéssemos nessa dupla noção entrever algo da passagem de um nível mais geral, no qual investimentos comuns estão colocados, para um vislumbre posterior desses detalhes onde um singular punge, estimula, fura.

De todo modo, o movimento contrário é também o movimento transmissivo do interesse fotográfico de Barthes, ou seja, a partir dos interesses particulares produz-se uma picada que pode estimular um interesse mais geral e por vezes produzir nos leitores (dos textos, das fotografias) acuidades particulares. Tomamos picada aqui tanto como sinônimo de pungir, picar, produzir um furo que requer atenção, como no sentido de trilha, estrada, "caminho aberto em mata fechada a golpes" (AULETE, 2020, s. p.).

Usamos essa palavra para fazê-la nossa, nos valendo de uma versão mais abrasileirada do furo ao qual Lacan (2003) faz referência no texto "Lituraterra" para definir - em posição próxima ao punctum barthesiano - o lugar da psicanálise, que 


\section{Criação \&}

aponta para o fracasso que faz furo no discurso instituído. Como mostra Marcus André Vieira (1999), Lacan toma o furo como uma extração de uma reta infinita, como o que está em torno dela, em oposição à concepção euclidiana, para qual o furo é interrupção. A partir disso, supomos esse intervalo escrito em Diário de Luto como um intervalo extraído a golpes, delimitando o que está em seu entorno, em vez de ser definido por ele.

Éric Marty (2009) descreve A câmara clara como uma descida ao reino das Sombras, um ato órfico, já que ali Barthes realiza um movimento próximo ao de Diário de Luto, a saber, a aproximação da questão da morte a partir das palavras, da escrita. Segundo Marty (2009), "falar da mãe para Barthes, não é ceder a uma fraqueza sentimental, é construir um livro - um túmulo -, ou seja, inventar novamente uma forma, desenhar volumes, produzir um tempo, criar uma fiç̧ão" (MARTY, 2009, p. 206).

No trecho seguinte do Diário de Luto, Barthes dá a ver esse ponto: "Meu luto é o de uma relação amorosa e não o de uma organização da vida. Ele vem a mim através das palavras (de amor) que surgem em minha cabeça..." (BARTHES, 2011, p. 38). Interessante pensar que o luto e essa nova forma de escrita apareça a partir de uma relação amorosa com as palavras e não a partir da organização da vida. Com essa última, poderíamos imaginar um plano preestabelecido, quase uma relação desencarnada, contrária ao que a relação amorosa com as palavras promove na escrita de Barthes.

Há ainda, nesse intervalo entre a morte da mãe e os princípios de Vita Nova, o curso sobre $O$ neutro, alguns textos espalhados por jornais e revistas, como nos mostra Nathalie Leger na nota inicial do Diário, até chegarmos por fim a algumas páginas escritas de Vita Nova e os dois cursos sobre $A$ preparação do romance. Sobre esses dois últimos projetos, Barthes diz:

Escrevo meu curso e chego a escrever Meu Romance. Penso então, com dor no coração, numa das últimas palavras de mam.: Meu Roland! Meu Roland! Tenho vontade de chorar. [Sem dúvida, estarei mal enquanto não escrever algo a partir dela (Foto ou outra coisa)]. (BARTHES, 2011, p. 212)

A partir dela introduz uma diferença em relação ao com ela, ou ao lado dela. Ainda que Barthes associe livremente, deslizando de Meu Romance para Meu Roland, o primeiro só se produz a partir do último, não colado nele. É a morte da mãe e, portanto, o fim da enunciação viva Meu Roland que insere um incomodo na lógica da escrita de Barthes e produz um novo, Meu Romance. Portanto, Diário de Luto, A câmara clara e Vita Nova (o romance, seu projeto, seu desejo) se escrevem a partir dela, a partir da morte dela, partindo, dividindo a contiguidade metonímica do livro a livro, do curso a curso. 


\section{Criação \&}

Ainda sobre o projeto do romance, na busca por uma forma para essa escrita e nos fracassos sucessivos dessa busca, Barthes associa diretamente sua escrita ao luto vivido. Para ele, "é como se acontecesse agora, claramente (retardada até então por sucessivos logros), a repercussão solene do luto sobre a possibilidade de fazer a obra. Prova maior, prova adulta, central, decisiva do luto" (BARTHES, 2011, p. 233).

O luto de Barthes parece suportável pela possibilidade de fazer a obra, de escrever, pela possibilidade de inscrever um dizer sobre essa incomensurabilidade do luto que não é exprimível. Como insere em seu diário: "Minha tristeza é inexprimível mas, apesar de tudo, dizível. O próprio fato de que a língua me fornece a palavra 'intolerável' realiza, imediatamente, certa tolerância" (BARTHES, 2011, p. 171). Há aqui uma diferença entre exprimível e dizível. A língua e o que ela toca de vivo realizam tolerância à tristeza, à morte. A escrita empresta novos contornos a essa dor e transmite tanto o que é dizível, quanto algo do que não é exprimível, mas de algum modo se insere no conjunto dessa escrita.

Por fim, em uma das últimas notas do diário, Barthes aponta a escrita como a construção de uma saída do lugar por vezes paralisante do luto. Não qualquer escrita, mas a literatura, apontando talvez aí a passagem tão almejada para um estilo de escrita outro, que não exclui o ensaio, do qual ele já estava tão habituado, mas inclui o romance, esse projeto levado a cabo por ele até seus últimos dias. Barthes diz: "Desde a morte de mam., não tenho mais vontade de 'construir' nada salvo na escrita. Por quê? Literatura = única região da Nobreza (como era mam.)" (BARTHES, 2011, p. 221).

Esse caminho aponta a função da escrita em Barthes no momento de seu luto, nesse intervalo entre a morte da mãe e o romance, qual seja, a manutenção da vida pela inscrição da morte. A escrita para Barthes nesse intervalo tem sentido próximo ao que seu amigo intelectual Blanchot define a palavra: "Ela é essa vida que carrega a morte e nela se mantém, a morte, o poder do prodigioso do negativo, ou ainda a liberdade, pelo trabalho de quem a existência é destacada dela mesma e tornada significativa" (BLANCHOT, 1997, p. 329-330).

\section{O trabalho do sonho}

Todo o diário de Barthes é tomado pelo registro de sonhos com a mãe, o primeiro datando de uma semana e meia depois da morte dela, e o último, quase dois anos depois. Entre sonhos alegres em que a reconquista de suas lembranças com ela são como que um alívio no processo do luto e sonhos de angústia, pesadelos nos quais coisas duras são ditas, emoções fortes aparecem, Barthes parece produzir com os sonhos e seu narrar uma travessia semelhante àquela efetuada na escrita. 


\section{Criação \&}

No primeiro sonho, Barthes recobra a vivência da mãe antes da doença que a acomete e tira-lhe a vida: "Esta noite, pela primeira vez, sonhei com ela; estava deitada, mas não doente, com sua camisola cor-de-rosa comprada no Uniprix..." (BARTHES, 2011, p. 34). No último dos sonhos registrados no diário, Barthes apresenta uma versão da mãe quase absoluta, como se fosse possível resgatá-la por completo a partir de um traço: o sorriso. Quase absoluta porque parcial. A tarefa operada no luto através dos recobramentos do vivido do sonho seria então estabelecer o que resta de uma mãe, o que resta de um ser amado que foi perdido, o que resta desse laço de amor: "Sesta. Sonho: exatamente seu sorriso. Sonho: lembrança integral, bem-sucedida" (BARTHES, 2011, p. 239). No entanto, vejamos o que se passa entre um sonho e outro, a narrativa onírica que Barthes constrói em seu trabalho de luto.

Quase a totalidade dos sonhos registrados no Diário de Luto de Barthes compõe-se de ocasiões em que aparecem os significantes pesadelo e sonho mau, enfim, passagens onde a angústia se coloca. Os sonhos de angústia foram uma das grandes categorias analisadas por Freud em seu texto seminal $A$ interpretação dos sonhos. Ali Freud (1996a) levanta a hipótese inicial de que os sonhos são a realização disfarçada de desejos recalcados, com algumas ressalvas aos sonhos de angústia e aos sonhos de punição, ainda que esses confirmem a ideia central.

Freud continua a reelaborar sua teoria dos sonhos em diversas ocasiões, em especial ao relacionar os sonhos traumáticos à compulsão à repetição que desvela o princípio da pulsão de morte. Em Revisão da Teoria dos Sonhos, a propósito da inclusão dos sonhos traumáticos em sua tese geral sobre a realização de desejos nos sonhos, Freud dirá: "Um sonho é uma tentativa de realização de um desejo. [...] Em determinadas circunstâncias, um sonho é capaz de levar a efeito a sua intenção de modo muito incompleto, ou, então, tem de abandoná-la por inteiro" (FREUD, 1996b, p. 38). Para Freud, o que resta do desejo neste tipo de sonho é um desejo de transmutação de traços mnêmicos traumáticos em direção à realização de desejo, o que falha em diversos momentos pelo despertar.

Um sonho a esse respeito já havia sido analisado por Freud no texto publicado em 1900. O sonho foi bastante trabalhado no meio analítico, mas cabe aqui reconstruí-lo parcialmente, para em seguida extrair dele o ponto que nos interessa e retomar os sonhos de Barthes.

Segundo Freud, o sonho foi ouvido em uma conferência por uma paciente que o relatou. Antes de contar o sonho, Freud sumariza o que passou anteriormente a ele: um pai estivera junto à cabeceira do leito do filho enfermo por dias seguidos, quando o filho morre, o pai deixa um senhor encarregado de velar o filho, enquanto ele vai para um quarto próximo descansar, deixando, no entanto, a porta entreaberta. O sonho: "O pai sonhou que seu filho estava de pé junto a sua cama, que o tomou pelo braço e lhe sussurrou em tom de censura: 'Pai, não vês que estou queimando?"' (FREUD, 1996a, p. 537). Quando desperta, o pai percebe que uma 


\section{Criação \&}

vela acesa tombara sobre o caixão do filho queimando parte de seu corpo, enquanto o senhor que deveria estar em vigília dormia.

Freud, fiel à sua teoria do sonho como realização de desejo, destaca em sua leitura do sonho, o desejo do pai de dormir para ver seu filho, por um momento, vivo. Lacan retoma esse sonho relatado por Freud a partir de uma questão: "O que é que desperta?" (LACAN, 2008, p. 62). Para Lacan, diferentemente de Freud, o que interrompe o sonho do pai não é o corpo do filho pegando fogo no quarto contíguo, mas a frase no interior do sonho, 'Pai, não vês que estou queimando?'. Como destaca Lacan, "esta frase, ela própria é uma tocha - ela sozinha põe fogo onde cai - e não vemos o que queima, pois a chama nos cega sobre o fato de que o fogo pega no Unterlegt, no Untertragen no real" (LACAN, 2008, p. 64).

Não é exatamente da dimensão significante que Lacan aqui trata, pelo menos não em sua vertente simbólica trabalhada em seminários anteriores, mas 0 que essa frase, essa tocha porta da dimensão real. Fazendo uso das figuras utilizadas por Freud, Unterlegt (suporte) e Untertragen (o que é 'jogado por baixo'), Lacan observa que o que desperta é "a realidade escondida por trás da falta do que tem lugar de representação" (LACAN, 2008, p. 64).

Então, para Lacan, não é a realidade que desperta, mas a palavra que ressoa no corpo. A frase surge no sonho como um resto irredutível, o que não tem representação no luto deste pai, fazendo furo na trama simbólica e o despertando do que poderia ser, como quisera Freud, um sonho para realizar um desejo, mesmo em tentativa.

O que fica desta distinção operada por Lacan do empreendimento freudiano não é tanto uma ode ao despertar, nem uma afirmação utópica do sonho, mas uma lembrança da capacidade e função onírica dos sujeitos, além da ideia de que, em todo sonho, reside um ponto opaco de representação, ou como adverte Freud: "Existe pelo menos um ponto em todo sonho ao qual ele é insondável - um umbigo, por assim dizer, que é seu ponto de contato com o desconhecido" (FREUD, 1996a, p. 145, nota de rodapé 2). Esse insondável é um elemento motriz do sonho, que o faz se inscrever no inconsciente, se repetir, é o que pode também fazer despertar, nos lembrando desta interface constante entre a vida de vigília e a vida onírica.

Retomando então os sonhos de Barthes inscritos no Diário de Luto, o recurso ao sonhar com a mãe, ainda que carregado de afetos angustiantes, remonta seu trajeto de escrita - até porque, é pela via da escrita que temos acesso a esses sonhos. É nessa imbricação entre escrita e sonho que o trabalho de luto de Barthes vai se dando.

No dia 17 de janeiro de 1978, Barthes registra: "Esta noite, pesadelos: mam. tomada por mal-estares" (BARTHES, 2011, p. 86). Em 25 de março de 1978: "Ontem, explico a Damisch que a emotividade passa, que o pesar fica - Ele me diz: Não, a emotividade volta, você verá. Esta noite, pesadelo com mamãe perdida. Fico transtornado, à beira das lágrimas" (BARTHES, 2011, p. 104). No primeiro sonho, a imagem da mãe com mal-estares, provavelmente as dores que a acometiam antes de sua morte; no segundo, a mãe perdida. Nos dois sonhos, os afetos se sobrepõem 


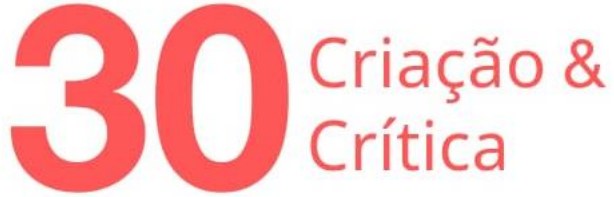

a uma ideia de que se pode ter controle do luto, de que se pode fazê-lo racionalmente de modo que a emotividade fique para trás e reste apenas o pesar, essa abstração intelectualizada do luto.

Ainda que carregue a carga dos afetos de angústia relatada anteriormente, no próximo registro, de modo ainda mais intenso, Barthes parece se aproximar dos sonhos que Freud nomeou de traumáticos, aqueles que, pela via de uma reinscrição no psiquismo, algo sem inscrição busca espaço. O sonho datado de 10 de maio de 1978: "Há várias noites, imagens - pesadelos em que vejo mam. doente, atacada. Terror. Sofro com o medo do que aconteceu. Cf. Winnicott: medo de um desmoronamento que já aconteceu" (BARTHES, 2011, p. 119).

Como aponta a nota da edição do diário, Barthes faz uma referência direta ao texto Fear of breakdown de Donald Winnicott. De forma sumarizada, tentando não perder de vista a complexidade desse texto, o fear of breakdown ou medo do desmoronamento em uma tradução rápida seria, para Winnicott, um "estado de coisas impensável que fundamenta a organização defensiva" (WINNICOTT, 1974, p. 103), incluindo medos de desintegração, despersonalização, capacidade de se relacionar com os objetos. Winnicott afirma que ansiedade não é uma palavra forte o bastante para descrever tais estados presentes tanto em quadros neuróticos quanto psicóticos.

Interessa, no entanto, um destaque bastante acurado feito por Winnicott. De acordo com sua experiência clínica, por vezes é preciso dizer ao paciente que esse medo que prejudica sua vida é o medo de algo que já aconteceu, ainda que do ponto de vista da constituição psíquica ele (o eu) não estivesse lá ainda para presenciar essa ocorrência. Como afirma Winnicott, um modo de sair desse impasse clínico é experienciar na transferência, no tempo presente, essa coisa temida que era ao mesmo tempo passada e futura.

Essa intuição também é anotada por Barthes em seu diário. O medo que o acomete nesses sonhos, provocando sofrimento, é aquele que havia presenciado na doença de sua mãe. Ainda que a experiência de Barthes não coincida exatamente com o fenômeno clínico descrito por Winnicott (ali esse acontecimento não é algo de que se pode dar testemunho), o sonhar e a narração do sonho apontam uma saída próxima do que Winnicott descrevia através da transferência. Experienciando uma outra vez no sonho e na escrita desse, o medo pode ir cedendo e dando lugar a outros afetos a serem investidos. Como afirma Winnicott, "apenas a partir da nãoexistência, a existência pode começar" (WINNICOTT, 1974, p. 107), a partir da inscrição de um medo que já aconteceu, a existência de algo novo toma lugar. Podemos observar isso claramente no sonho seguinte, anotado por Barthes em seu diário. No dia 18 de julho de 1978, Barthes escreve:

Sonhei de novo com mam. Ela me dizia - ó crueldade - que eu não a amava muito. Mas isso me deixava calmo, tanto eu sabia que era falso. Ideia de que a morte seja um sono. Mas seria horrível se fosse 


\section{Criação \&}

preciso sonhar eternamente. (E hoje cedo, seu aniversário. Eu lhe oferecia sempre uma rosa. Compro duas no mercadinho de Mers Sultan e ponho-as em minha mesa). (BARTHES, 2011, p. 157)

O sonho apresenta inicialmente um caráter angustiante, a mãe dizendo a Barthes que ele não a amava tanto. Mas logo depois um passo para fora disso: uma calma proveniente do fato de que esse dizer fosse falso. Esse distanciamento destacado no sonho acima não podia estar presente nos anteriores, uma vez que o medo disso que já aconteceu era excessivo em relação a qualquer outra sensação a respeito do sonho. Mesmo que a cessação desse excesso abra espaço pra outras impressões, isso não quer dizer que sonhos angustiantes ou traumáticos não vão se fazer presentes dali pra frente, mas agora pode-se contar com outro recurso, algum distanciamento que não impede de se afetar, mas permite afetar-se de outro modo. Nesse sentido, cabe acrescentar que no relato mesmo desse sonho, Barthes repete um gesto comum da convivência com sua mãe em vida, a compra de rosas por ocasião do aniversário dela. Desse modo, convém marcar que não há apenas ruptura ou o acesso a um novo recurso, mas também recuos, inclusive como artifício para não deixar que a mãe submerja para sempre na morte.

Esse aspecto da separação, da distância como um novo (não o único) recurso faz-se presente também nos dois registros seguintes sobre os sonhos. Em 18 de março de 1979: "Na noite passada, sonho mau. Cena com mam. Dissensão, dor, soluços: eu estava separado dela por alguma coisa (decisão da parte dela?) de espiritual. Sua decisão concernia também a Michel. Ela estava inacessível" (BARTHES, 2011, p. 228). No mesmo dia, em outra ficha: "Cada vez que sonho com ela (e só com ela), é para vê-la, acreditar que ela tá viva, mas outra, separada” (BARTHES, 2011, p. 229).

Tendo percorrido a totalidade da incidência dos sonhos nos fragmentos do Diário de Luto de Roland Barthes, depreendemos uma narrativa onírica. Nos aproximamos aqui do desejo de romance de Barthes, ocasionado após a morte de sua mãe, respeitando o caráter singular de cada um desses fragmentos e sua resistência ao contínuo. Não se trata de forçar uma narrativa coesa, mas de demarcar o que se pode extrair dessa travessia de fragmentos, lidos um a um.

O luto de Barthes vai tendo inscrição a partir do trabalho de sonho associado ao trabalho de escrita. De uma emoção da qual se vê atrelado chegando a um traço - o sorriso que resta da mãe - passando por uma separação, um distanciamento que se apresenta para que o luto possa se inscrever em outro lugar, no texto. $O$ intervalo entre a morte da mãe e o desejo de uma outra escrita é ocupado por essa elaboração onírica que faz parte da construção do diário.

Barthes se detém sobre o significante trabalho tão associado ao luto e ao sonho: 


\section{Criação \&}

O quase: regime atroz do amor, mas também estatuto decepcionante do sonho - por isso odeio os sonhos. Pois com frequência sonho com ela (só sonho com ela), mas jamais é inteiramente ela: ela às vezes tem, no sonho, alguma coisa de um pouco deslocado, de excessivo: por exemplo, jovial ou desenvolta - o que ela jamais era; ou ainda, sei que é ela, mas não vejo seus traços (mas será que no sonho se vê ou se sabe?): sonho com ela, não a sonho. E diante da foto, como no sonho, trata-se do mesmo esforço, do mesmo trabalho sisifino: remontar, aplicado, para a essência, descer novamente sem tê-la contemplado, e recomeçar. (BARTHES, 1984, pp. 99-100)

A redução que a operação do luto produz da narrativa ao traço parece evidenciar a drenagem imaginária do drama do luto, na direção da extração desse elemento a um tempo simbólico e real. $\mathrm{O}$ traço aparece como a herança da qual o sujeito se apropria para recomeçar, reler o Outro.

Sonho com ela, não a sonho. Distinção operada por esse trabalho que para Barthes remete ao trabalho de Sísifo: rolar com a pedra acima, vê-la rolar para baixo, remontar, recomeçar. Barthes destaca nessa passagem o aspecto deslocado da representação da mãe em alguns sonhos. Freud afirma que o trabalho do sonho: "Não pensa, não calcula e nem julga de nenhum modo; restringe-se a dar às coisas uma nova forma" (FREUD, 1996a, p. 534). Para que possam superar a censura, no sonho as intensidades psíquicas são deslocadas produzindo uma "transmutação de todos os valores psíquicos" (FREUD, 1996a, p. 535).

Desse modo, esse deslocamento operado em um sonho também pode ser observado quando se coloca um sonho em relação a outro. O insuportável das dores e do sofrimento materno cede lugar a um aspecto restante da mãe, travessia possível que inclui na escrita a narrativa onírica e o trabalho de luto. A palavra trabalho insiste:

Não é de solidão que necessito, é de anonimato (de trabalho). Transformo "Trabalho" no sentido psicanalítico (Trabalho do Luto, do Sonho) em "Trabalho" real - de escrita. Pois: O "Trabalho" pelo qual (dizem) saímos das grandes crises (amor, luto) não deve ser liquidado apressadamente; para mim, ele só se realiza na e pela escrita. (BARTHES, 2011, p. 129)

O trabalho "real" de escrita de Barthes está impregnado do trabalho psíquico do luto e do sonho. Barthes afirma: "Não suprimir o luto (a dor) (ideia estúpida do tempo que abolirá), mas mudá-lo, transformá-lo, fazê-lo passar de um estado estático (estase, entupimento, recorrências repetitivas do idêntico) a um estado fluido" (BARTHES, 2011, p. 139). Fazer o luto passar, deixá-lo passar através da possibilidade de narrá-lo, fazendo da repetição uma travessia. Transmitir o singular 


\section{Criação \&}

do sonho através da forma fragmentária até aceder a um estado não contínuo, mas fluido. Cabe também ali o singular de cada leitor que se depara com o que se transmite, mas também com 0 que resta intransmissível, irrepresentável, preservando o lugar do desconhecido, do deslocado, esse ponto de mais real que por vezes desperta, por outras nos convoca a sonhar outra vez.

\section{O trabalho do luto}

Freud, em Luto e melancolia, opera com essas duas facetas da perda de objeto que intitulam o texto. Em uma primeira leitura, pode parecer que Freud se dedica menos à situação do enlutado, tratando dessa condição apenas em comparação com o que realmente Ihe faria questão, o melancólico. De todo modo, é preciso lembrar, como já havia sido indicado por Freud em outro texto, que "a fim de chegar à compreensão do que parece tão simples em fenômenos normais, teremos de recorrer ao campo da patologia com suas distorções e exageros" (FREUD, 1996c, p. 89).

Esses limites sempre tênues entre normal e patológico, no texto freudiano muitas vezes se transformam em ponto de contato. Essa perspectiva interessa para escapar de uma abordagem normativa de uma situação tão delicada, criando separações rígidas para o que é tão subjetivo. A aproximação de uma definição do processo de luto em Freud é aberta o suficiente para abarcar essa delicadeza: "O luto, via de regra, é a reação à perda de uma pessoa querida ou de uma abstração que esteja no lugar dela, como pátria, liberdade, ideal etc." (FREUD, 2011, p. 47). A palavra reação usada não incorre no erro de predeterminar o que essa reação será e prejulgá-la como normal.

$\mathrm{Na}$ verdade, Freud indica que o luto manifesta três estados também presentes na melancolia:

O luto profundo, a reação à perda de uma pessoa amada, contêm o mesmo estado de ânimo doloroso, a perda de interesse pelo mundo externo - na medida em que este não faz lembrar o morto -, a perda da capacidade de escolher um novo objeto de amor - em substituição ao pranteado - e o afastamento de toda e qualquer atividade que não tiver relação com a memória do morto. (FREUD, 2011, p. 47)

A diferença estaria, para Freud, na ausência das autorrecriminações e dos autoinsultos que podem desencadear delírio de autopunição, presentes na melancolia. $O$ trabalho do luto estaria mais atrelado ao abandono da uma posição libidinal de investimento naquele objeto ou naquele laço com o outro perdido. Ainda que Freud aponte que essa tarefa leva tempo e energia para ser cumprida, não atrela a esse processo nenhum tipo prescrição de como ele vai ser realizado. Importa mais que "uma a uma, as lembranças, as expectativas pelas quais a libido 


\section{Criação \&}

se ligava ao objeto são focalizadas e superinvestidas e nelas se realiza o desligamento da libido" (FREUD, 2011, p. 49).

No Diário de Luto de Barthes, fica bem destacada uma outra dimensão do trabalho do luto: "que essa morte não me destrua completamente, isso significa que decididamente desejo viver perdidamente, até a loucura, e que, portanto, o medo de minha própria morte continua aqui, não foi deslocado nem uma polegada" (BARTHES, 2011, p. 21). Apesar da dor dilacerante que o aflige, resta para Barthes ainda assim um núcleo resistente, um desejo de vida, um desejo de que a vida atravesse a morte.

Ao anunciar uma expectativa de que a morte não o destrua completamente, Barthes parece pressentir ali que algo de fato é destruído pela morte. Esse algo incerto é construído ao longo do diário, no registro do transcorrer dos dias, das memórias. Posteriormente a renúncia do mais singular em sua posição libidinal em relação à mãe resulta como Freud aponta, no prêmio de consolação de permanecer vivo, segundo o desejo de Barthes: "agora, coragem significaria querer viver, e esta a gente tem até demais" (BARTHES, 2011, p. 40).

No passo conjunto de sua escrita e de seu luto, Barthes acaba se havendo com a dimensão temporal. Sobre isso, escreve: "Assusta-me absolutamente o caráter descontínuo do luto" (BARTHES, 2011, p. 65). Anota ainda no dia 18 de fevereiro de 1978: "Luto: aprendi que ele é imutável e esporádico: ele não se desgasta, porque não é contínuo" (BARTHES, 2011, p. 92). O aspecto descontínuo percebido por ele aponta para o que não vai ser superado, desgastado, porque não é algo, para Barthes, prolongado no tempo, sem interrupção. Seu luto vai sendo retomado, descontinuamente, tão fragmentário quanto sua escrita.

Sobre a relação entre tempo e luto, Maria Rita Kehl em seu trabalho sobre as depressões observa:

O luto demanda tempo; este tem a função de proteger o psiquismo da desorganização causada pela perda. Mas o tempo do luto não se limita ao transcorrer de um determinado prazo: ele implica também a reconstrução de um novo ritmo compatível com novas modalidades de ausência e presença do objeto e de sua representação. A reorganização do campo de representações psíquicas e da circulação pulsional que ele determina implica também a dimensão rítmica da temporalidade, cuja representação mais conhecida em psicanálise é a alternância da ausência e da presença do objeto - o jogo do fort-da observado por Freud em um de seus netos. (KEHL, 2009, p. 206)

O ritmo em substituição ao prazo, a alternância entre presença e ausência, a presentificação da ausência de forma ativa - como no fort-da - através da escrita. Barthes vai reconstruindo uma nova relação com o tempo para abarcar sua nova 


\section{Criação \&}

relação singular com o mundo ou como ele mesmo prescreve: "a cada um seu ritmo de sofrimento" (BARTHES, 2011, p. 158).

Em O prazer do texto, Barthes (1987) retoma essa relação descontínua com os objetos - que certamente inclui a repetição - contida no jogo do fort-da:

Nenhum objeto está numa relação constante com o prazer (Lacan, a propósito de Sade). Entretanto, para o escritor, esse objeto existe; não é a linguagem, é a língua, a língua materna. O escritor é alguém que brinca com o corpo da mãe (remeto a Pleynet, sobre Lautréamont e sobre Matisse): para o glorificar, para o embelezar, ou para o despedaçar, para o levar ao limite daquilo que, do corpo, pode ser reconhecido: eu iria a ponto de gozar de uma desfiguração da língua, e a opinião pública soltaria grandes gritos, pois ela não quer que se 'desfigure' a natureza. (BARTHES, 1987, p. 50, tradução modificada).

No fort-da, a reencenação ativa da perda da mãe, inicialmente experimentada de forma passiva, aparece como meio de negociação constante entre por um lado, novos recursos possíveis, novos modos de lidar com a perda e, por outro, um retorno à figura da mãe na tentativa de construção de memoriais possíveis dessa ausência. Na escrita do Diário de Luto, Barthes vivifica sua construção teórica do escritor como alguém que brinca com o corpo da mãe. A partir das lembranças, dos sonhos, das repetições, dos novos modos de gozo acrescentados aos antigos, Barthes dá a ver o despedaçamento, a desfiguração da língua como modo de brincar/gozar com o corpo da mãe, ou em outros termos, com o corpo da língua. A repetição é justamente o que permite que o novo se inclua. A reinscrição das formas é ocasião para observar o que nessa repetição se destaca.

$\mathrm{Na}$ construção desse novo ritmo balizado por um tempo descontínuo, Barthes realiza uma negociação constante entre investimento e desinvestimento, resistência ao abandono de uma posição libidinal e o consentimento com que isso ceda: "Como o amor, o luto torna o mundo, o mundano, o irreal, inoportuno. Resisto ao mundo, sofro com o que ele me pede, com sua demanda. $O$ mundo aumenta minha tristeza, minha secura, meu desassossego, minha irritação, etc. O mundo me deprime" (BARTHES, 2011, p. 123). O luto de Barthes vai se constituindo como uma negociação não-contratual entre o desejo de permanecer vivo e o assentimento com a perda. Não se negocia, no entanto, a partir de um acordo pré-estabelecido, mas a partir das emotividades e pesares que atravessam esse sujeito.

No dia 18 de agosto de 1978, Barthes escreve:

Continuar "falando" com mam. (a fala partilhada sendo a presença) não é um discurso interior (nunca "falei" com ela), mas um modo de vida: tento viver cotidianamente segundo seus valores: cozinhando eu mesmo, reencontrar um pouco da comida que ela fazia, manter 


\section{Criação \&}

sua ordem caseira, aquela aliança de ética e estética que era sua maneira incomparável de viver, de agir no cotidiano. (BARTHES, 2011, p. 186)

Barthes vai resgatando os atributos de sua mãe, não sem se incluir ali, estabelecendo um novo modo de vida, um novo lugar a partir de alguns elementos perdidos na posição anterior. Como aponta Carolina Koretzky: "o trabalho do luto será menos de enumerar os traços do morto investidos libidinalmente do que perceber o objeto que eu mesmo era para o falecido como causa de seu desejo" (KORETZKY, 2019, p. 191).

A partir desse ponto, da causa de desejo, Barthes vai encontrando seu lugar, sua implicação e investimento em relação à mãe. Em um episódio, depois de ouvir o rádio e ler uma passagem de Bashô sobre o silêncio, escreve: "experimento imediatamente uma espécie de satori ${ }^{3}$, doce, feliz, como se meu luto se acalmasse, se sublimasse, se reconciliasse, se aprofundasse sem se anular - como se 'eu me reencontrasse"' (BARTHES, 2011, p. 185).

Mais uma vez, Koretzky indica sobre essa travessia:

o trabalho analítico nos momentos de luto permite um acesso em direção a um para além do amor, em direção a um objeto que o amor reveste. A psicanálise não propõe resolver a tristeza nem curar a perda, mas obter pelo trabalho associativo sob transferência, um ganho de saber. Esse saber não concerne nada menos que isso que, na perda e na falta, pode causar e sustentar o ser de desejo de um sujeito. (KORETZKY, 2019, pp. 191-192)

Sem a anulação de seu luto, sem a superação da tristeza, mas com a possibilidade de também se alegrar, Barthes recobra em seu investimento, um novo lugar alcançado na travessia do processo de luto. Esse novo modo de vida não idealizado pode ter sido um ganho de saber obtido através do consentimento ao abandono de uma posição libidinal, mas, no caso de Barthes, se esse ganho de saber estava sob transferência, essa era endereçada à escrita, à letra inscrita nessa travessia. Em suas palavras: "Há, portanto, no luto (o deste tipo, o meu), uma apreensão radical e nova da morte; porque antes era apenas um saber emprestado (canhestro, vindo dos outros, da filosofia etc.), mas agora é meu saber. Ele não pode doer mais do que meu luto" (BARTHES, 2011, p. 116).

${ }^{3}$ Em um dos cursos no College de France, o satori (essa palavra eminentemente oriental) aparece como uma das figuras do neutro. Barthes (2003a) apresenta essa experiência como um abalo no conhecimento e na linguagem, uma desestabilização na lógica vigente, não para introdução de uma nova verdade ou certeza, "mas sim súbito desembocar no vazio" (p. 357). Barthes (2003a) traz ainda como exemplo ocidental de satori, a madeleine de Proust no princípio da Busca: o tilintar da xícara de chá, o guardanapo e o sabor da madeleine suspendem a dúvida intelectual e as preocupações sobre o futuro. 


\section{Criação \&}

\section{Um pássaro de canto particular, literário}

Numa das primeiras fichas do diário, Barthes recupera os últimos dias de sua mãe em vida em uma fala que ela o endereça: 'Aqui está'. Esta fala é oportunidade para associá-la a outra memória: "(Aqui estou, foi o que nós dissemos um ao outro durante toda a vida)" (BARTHES, 2011, p . 36). A partir disso, Barthes indica que seu luto não está em sua solidão, ainda menos na experiência empírica do sofrimento; para ele, seu luto "está ali onde se redilacera a relação de amor, o 'nós nos amávamos'. O ponto mais ardente no mais abstrato dos pontos..." (BARTHES, 2011, p. 36).

Nessa relação de amor, no tormento retomado do amor, encontramos o enunciado proferido pela narrativa construída no diário: Aqui estou, esse é o enunciado do enlutado, Roland Barthes em sua escrita do luto. Em direção paralela ao seu dito 'Aqui estou', está seu dizer extraído daí, sua enunciação, podendo ser assim escrita: Aqui estou, sobrevivi à sua morte.

Barthes recorda ainda uma outra fala de sua mãe: "('Meu R, meu R' - 'Estou aqui' - 'Você está mal sentado')" (BARTHES, 2011, p. 39). Daí podemos extrair ou desdobrar ainda sua enunciação: Estou aqui, vivo, marcado pela sua morte, por isso ainda mais vivo. Depois da sobrevivência, de sobreviver à morte, um nó se impõe na vida e ao invés de desenrolá-lo, como poderia ser esperado, permanecer vivo exige enodar a vida de outra forma, o que Barthes opera em sua escrita.

Ainda no diário, em anotação feita numa manhã de sol em viagem ao Marrocos, Barthes ouve entre os ruídos do campo e um motor "um pássaro de canto particular" ao qual designa literário: "Manhã. Sol, um pássaro de canto particular, literário, ruídos do campo (um motor), solidão, paz, nenhuma agressão" (BARTHES, 2011, p. 162). Uma escuta que retira da ordem cronológica do tempo um ritmo, um olhar que extrai da paisagem uma imagem onírica, uma leitura do mundo que produz escrita com o corpo.

Nesse caminho em direção a esse canto particular da literatura, ou pelo menos em um desejo por ela, Barthes chegou mais próximo nas páginas batidas à máquina de escrever depositadas em sua mesa e encontradas posteriormente ao atropelamento que desencadeia em sua própria morte. Essas páginas foram intituladas sob as mesmas palavras que abrem $A$ busca do tempo perdido de Proust: Durante muito tempo fui dormir cedo.

E foi ele também, Marcel Proust, que em sua escrita monta a cena do encontro com esse pássaro para ali ler uma outra ordenação:

A zona de tristeza em que eu acabava de penetrar era tão diversa da zona em que um momento antes me lançava alegremente quanto em alguns céus se mostra uma faixa cor-de-rosa separada, como por uma linha, de uma faixa verde ou de uma faixa negra. Vê-se um 


\section{Criação \&}

pássaro voando no rosa, já vai chegando a seu limite, quase que toca o negro, atinge-o finalmente. Os desejos que ainda há pouco me assediavam, de ir a Guermantes, de viajar, de ser feliz, eram-me agora tão estranhos que sua realização não me causaria prazer algum. (PROUST, 2016, p. 231)

A faixa cor-de-rosa é a faixa destacada onde é possível inicialmente ver o pássaro. O narrador da Busca observa que o pássaro quase transpõe o limite, para depois, em seguida, transpô-lo. Essa transposição é o mote para testemunhar que os prazeres que o sondavam anteriormente não teriam mais o mesmo efeito. É como se, tanto Proust como Barthes, em suas convivências na escrita com os pássaros, pudessem destacar a liberdade da forma como efeito da transposição de um prazer precedente. Ou ainda como o próprio Barthes indica: "o prazer que cai, cai para sempre, insubstituível. Outros prazeres vêm, que não substituem nada. Não há progresso nos prazeres, apenas mutações" (BARTHES, 2003b, p. 63).

No texto em que Barthes escreve inspirado em Proust, ele escreve e age sob uma distinção encontrada por ele no autor da Busca. Para Barthes, depois da hesitação, Proust fica, em sua escrita entre a metáfora (esse lugar do "o que isso quer dizer", presente no ensaio) e a metonímia (espaço onde se pergunta "de que isso pode ser seguido?", forma tradicional do romance). Como aponta Barthes, no revolver na cama das cinquenta primeiras páginas da Busca de Proust, abala-se a cronologia e produz-se uma terceira forma.

Nessa outra escrita, há dois elementos importantes: a desorganização temporal produz um deslocamento da voz narrativa passando de um eu que lembra e confessa para um eu que enuncia "cujas ligações com o 'eu' civil são incertas, deslocadas" (BARTHES, 1988, p. 288); e uma narrativa não cronológica que quer menos contar uma história e mais inscrever um desejo de escrever, ainda que avisado de seus malogros.

Assim, damos as mãos a Barthes em direção à cena final, a um fim que engendra em seu interior um começo:

Esse Romance utópico, importa-me fazer como se devesse escrevêlo. E reencontro aqui, para terminar, o método. Coloco-me realmente na posição de quem faz alguma coisa, e não mais de quem fala sobre alguma coisa: não estudo um produto, endosso uma produção; elimino o discurso sobre o discurso; o mundo já não vem a mim sob forma de um objeto, mas sob a de uma escritura, quer dizer, de uma prática: passo para outro tipo de saber (o do Amador) e é nisso que sou metódico. (BARTHES, 1988, pp. 293-294)

Nesse saber construído às custas do atravessamento da morte de sua mãe, Barthes é compelido a transformar sua enunciação, seu modo de enunciar que até 


\section{Criação \&}

então the parecia satisfatório. Nesse intervalo criado pela prática de anotação do diário, Barthes constrói uma paisagem escritural onde a negociação entre investimento e desinvestimento do luto, tão carregado dos traços do "eu" perdidos na relação com a mãe abre passagem para um saber amador que suporta não falar sobre algo, sobre si, mas escrever a partir dessa busca por outra cena enunciativa.

Aí se inscreve um desejo nomeado por Barthes como Querer-Escrever: "Dizer que se quer escrever, eis, de fato, a própria matéria da escritura... não se pode, portanto, dizer o Querer-Escrever senão na língua do Escrever" (BARTHES, 2005, p. 17). A vida nova barthesiana acontece na escrita, um desejo não apenas ali formulado, mas ali também operado. Essa vida nova que engendra a morte de uma vida anterior: a da escrita ("Não, Sísifo não é feliz: ele é alienado, não pela inutilidade de seu trabalho, mas por sua repetição" (BARTHES, 2005, p. 7) e também a vida anterior partilhada com sua mãe que faz eclodir todo esse novo querer.

Barthes observa que Proust escreve para se salvar e resistir à morte daqueles que ama, afirmando que "toda narrativa mítica recita (conta) que a morte serve para alguma coisa" (BARTHES, 2005, p. 18). Desse modo, Barthes parece refazer o movimento proustiano, tornando-o também seu, justapondo no limite a pergunta da forma ensaio sobre o sentido e a pergunta do romance sobre o efeito.

Nesse intervalo, entre a morte da mãe e a possibilidade de uma nova vida, o diário aparece para Barthes, conforme indica Pino (2015), como a oportunidade do escritor de produzir um discurso crítico sobre a sua própria escrita, em anotação seguinte do próprio diário ou ainda em reflexão produzida pelo leitor. Para Pino (2015): "Barthes percebe um certo prazer do diário, que não está nem no processo de escrita, nem na justeza do texto final, mas na rememoração daquilo que, de fato, não coube na anotação" (PINO, 2015, p. 31). A partir desse prazer ali destacado, Barthes faz outra coisa da anotação no diário, usando-a como mote para o desejo de escrever, para o desejo de uma nova forma de escrita. Isso de algum modo é possível para Barthes trazendo a morte para a vida, para então viver melhor, ou pelo menos viver e escrever de outro modo, inscrevendo novos desejos.

\section{Referências}

AESCHIMAN, E. Désaccords autour des notes posthumes de Roland Barthes. Libération. 21 de janeiro de 2009. Disponível em: https://www.liberation.fr/culture/2009/01/21/desaccords-autour-des-notesposthumes-de-roland-barthes_304293/

AULETE, C. Aulete Digital - Dicionário contemporâneo da língua portuguesa: Dicionário Caldas Aulete. Disponível em: https://www.aulete.com.br/site.php?mdl=aulete_digital. Acesso em: 18 ago. 2020.

BARTHES, R. A câmara clara. Rio de Janeiro: Nova Fronteira, 1984.

BARTHES, R. O prazer do texto. São Paulo: Editora Perspectiva, 1987.

BARTHES, R. "Durante muito tempo fui dormir cedo". In: O rumor da língua. São Paulo: Editora Brasiliense, 1988, pp. 283-294. 


\section{Criação \&}

BARTHES, R. O neutro: anotações de aulas e seminários ministrados no Collège de France, 1977-1978. São Paulo: Martins Fontes, 2003a.

BARTHES, R. Roland Barthes por Roland Barthes. São Paulo: Estação Liberdade, 2003b.

BARTHES, R. Isso pega. In: Inéditos: vol. 2 - Crítica. São Paulo: Martins Fontes, 2004, pp. 225-229.

BARTHES, R. A preparação do romance l: da vida à obra. São Paulo: Martins Fontes, 2005.

BARTHES, R. Diário de Luto. São Paulo: Martins Fontes, 2011.

BLANCHOT, M. A parte do fogo. Rio de Janeiro: Rocco, 1997.

FREUD, S. A interpretação dos sonhos II(1900-1901). vol. V. Rio de Janeiro: Imago, 1996a, ESB.

FREUD, S. Revisão da teoria dos sonhos (1933 [1932]). vol. XXII. Rio de Janeiro: Imago, 1996b, ESB.

FREUD, S. Sobre o narcisismo: uma introdução (1914). Vol. XIV. Rio de Janeiro: Imago, 1996c, ESB.

FREUD, S. Luto e melancolia (1917). São Paulo: Cosac Naify, 2011.

KEHL, M. R. O tempo e o cão: a atualidade das depressões. São Paulo: Boitempo, 2009.

KORETZKY, C. Le deuil, le rêve et son au-delà. In: HULAK, Fabienne (Coord.). Lire Lacan au XXle Siécle. Paris: Champ Social Editions, 2019, pp. 180-193.

LACAN, J. "Abertura desta coletânea". In: LACAN, J. Escritos. Rio de Janeiro: Zahar, 1998, p. 9-21. LACAN, J. "Lituraterra" (1971). In: Outros Escritos. Rio de Janeiro: Zahar, 2003, pp. 15-25.

LACAN, J. O seminário, livro 11: os quatro conceitos fundamentais da psicanálise. (1964). Rio de Janeiro: Zahar, 2008.

LACAN, J. A transmissão - Encerramento do 9 Congresso da Escola Freudiana de Paris (1978). In: Correio APPOA, n. 246, 2015. Disponível em: http://www.appoa.org.br/correio/edicao/246/sumario/212. Acesso em: 30 ago. 2020. MARTY, É. Roland Barthes, o ofício de escrever: ensaio. Rio de Janeiro: DIFEL, 2009.

PINO, C. Roland Barthes: a aventura do romance. Rio de Janeiro: 7 letras, 2015.

PROUST, M. Em busca do tempo perdido: no caminho de Swann. São Paulo: Biblioteca Azul, 2016.

STERZI, E. Incipit: A Vita Nova e a irrupção da lírica moderna. Tese de Doutorado apresentada ao Programa de Pós-Graduação em Teoria e História Literária, IELUnicamp, $2006 . \quad$ Disponível em: http://repositorio.unicamp.br/jspui/handle/REPOSIP/270285. Acesso em: 02 ago. 2020.

TROCOLI, F. Ali onde eu não interpreto, isso corta. Lacuna: uma revista de psicanálise, São Paulo, n. 3, p. 6, 2017. Disponível em: https://revistalacuna.com/2017/04/28/n3-06/. Acesso em: 01 ago. 2020.

VIEIRA, M. A. Cogitações sobre o furo. Ágora - Estudos em Teoria Psicanalítica, Rio de Janeiro, v. II, n. 2, p. 4, 1999.

WINNICOTT, D. Fear of breakdown. International Review of Psycho-Analysis, n. 1, pp. 103-107, 1974.

Recebido em: 15/04/2021 Aceito em: 01/07/2021

Referência eletrônica: FIDELIS, Kaio; ROCHA, Guilherme Massara. Um pássaro de canto particular, literário: A paisagem escritural barthesiana e a inscrição da morte na vida. Criação \& Crítica, n. 30, p., set. 2021. Disponível em: <http://revistas.usp.br/criacaoecritica>. Acesso em: dd mmm. aaaa 